\title{
PHYSICAL-RECREATIONAL ACTIVITIES AND PERSONS WITH DISABILITY
}

\author{
Srećko Potić, High Medical School of Professional Studies "Milutin Milanković", Belgrade \\ Ksenija Stanimirov, University of Belgrade, Faculty of Special Education and Rehabilitation,
} Belgrade

Mirjana Đorđević, University of Belgrade, Faculty of Special Education and Rehabilitation, Belgrade

Slobodan Banković, University of Belgrade, Faculty of Special Education and Rehabilitation, Belgrade

\section{Abstract}

Recreational activities represent individual or organised group activities chosen by free will, which help individuals to maintain good health, physical and working condition. In addition to the required physical segment, recreation also includes mental component which refers to strengthening of the will and determination, acquisition and development of self-control. With physical and mental aspect of recreational activities, many authors especially emphasize the importance of socio-psychological component of recreation.

The aim of this paper is to review the so far published scientific and professional works in which the problem of recreational activities of persons with cerebral palsy, sight impairment, intellectual disability and autism is discussed, by studying the available literature. During the research we used the electronic data base of Serbian Library Consortium for Coordinated Acquisition, Google Scholar, as well as published material available in print.

The participation of persons with disabilities in physical-recreational activities in the community is determined by the individual characteristics of the person, but with the community factors as well. The results of many studies show that persons with disabilities participate less in leisure and physical recreational activities and that is largely related to the level of social integration of these persons.

Taking into account the fact that the participation of persons with disabilities in physical-recreational activities largely correlates with the quality of life of these persons, it is necessary to increase the number of recreational services that the community offers, as well as to specialise, modify and adapt some of them in relation to the needs of these persons. Also, it is recommended that as an integral part of all therapeutic approaches to persons with disability, the training of these persons for the appropriate use of their leisure time be included.

Keywords: Physical activities, Recreational activities, Disability, Autism, Cerebral Pal

\section{REKREATIVNE AKTIVNOSTI OSOBA SA INVALIDITETOM}

\section{Sažetak}

Rekreativne aktivnosti predstavljaju slobodno izabrane, individualne ili organizovane grupne aktivnosti koje pomažu pojedincu da održi dobro zdravlje, fizičku i radnu kondiciju. Pored neophodnog fizičkog segmenta, rekreacija obuhvata i psihičku komponentu koja se odnosi na jačanje volje i istrajnosti, sticanje i razvijanje samokontrole. Uz psihički i fizički aspekt rekreativnih aktivnosti, mnogi autori posebno ističu važnost socio-psihološke komponente rekreacije. 
Cilj ovog rada je da se uvidom u dostupnu literaturu, napravi pregled dosadašnjih stručnih i naučnih radova u kojima je obrađivana problematika fizičko-rekreativnih aktivnosti osoba sa cerebralnom paralizom, oštećenjem vida, intelektualnom ometenošću i autizmom. Pri izradi ovog pregleda korišćene su elektronske baze podataka Konzorcijuma biblioteka Srbije za objedinjenu nabavku, Google Scholar, kao i publikovani materijali dostupni u štampanoj verziji. Učešće osoba sa invaliditetom u fizičko-rekreativnim aktivnostima u zajednici determinisano je individualnim karakteristikama same osobe, ali i faktorima društvene zajednice. Rezultati mnogih istraživanja pokazuju da osobe sa invaliditetom slabije participiraju u slobodnim i fizičko-rekreativnim aktivnostima i da je to u velikoj meri povezano sa nivoom socijalne integracije ovih osoba.

Imajući u vidu da učešće osoba sa invaliditetom u fizičko-rekreativnim aktivnostima u velikoj meri korelira sa kvalitetom života ovih osoba, potrebno je da se poveća broj rekreativnih usluga koje zajednica nudi osobama sa invaliditetom, kao i da se neke od njih specijalizuju, modifikuju i prilagode u skladu sa potrebama ovih osoba. Takođe, preporučuje se da sastavni deo svih terapijskih pristupa osobama sa invaliditetom bude i obuka ovih osoba za adekvatno korišćenje slobodnog vremena.

Ključne reči: Rekreativne aktivnosti, Autizam, Intelektualna ometenost, Cerebralna paraliza

TIMS Acta (2014) 8, 71-80

\section{Introduction}

Recreational activities represent freely chosen, individual or organised group activities that help one to maintain good health, physical and working shape. In addition to necessary physical segment, recreation also includes psychological component that relates to the strengthening of will and persistence, acquiring and developing of self-control. Along with psychological and physical aspect of recreational activities, many authors put special emphasis on the importance of socio-psychological component of recreation.

It should be kept in mind that different authors have defined recreational activities differently, in such a way that the extent or inclusiveness of recreational activities, as term, varies. For example, Ashwortha et al. (2009), beside physical activity, exercising or sports, in recreational activities include activities such as playing cards, computer activities, reading, watching television, listening to the radio, while Solish et al. (2010) make a distinction between recreational and leisure activities. Physical activity in daily life can be categorised into occupational, sports, conditioning, household, or other activities (Caspersen et al., 1985). Different definitions of recreational activities in studies make comparing of the results and generalization of the findings difficult.

The aim of this study was to examine the available literature and make a review of the current scientific and research papers in which issues of physical-recreational activities of persons with physical disabilities, visual impairments, intellectual disability and autism were elaborated. Electronic databases of Serbian Library Consortium for Coordinated Acquisition, Google Scholar, and published materials available in printed version were used in preparing of this survey.

\section{Physical-recreational activities and persons with visual impairments}

Physical activity is very important for good general health, physical fitness and quality of life. When it comes to children with visual impairment, it is important to point out that they have the same needs for physical activities as their peers from general population. However, the problem is that less choice of recreational and physical activities is generally offered to blind and partially sighted children. It is important to emphasize that, when they are given the opportunity and when they have adequate support, children with visual impairment can develop skills and stamina similar to that of children with typical development. Participation in physical activities helps in personality development, and enforces both self-confidence and independence, and it is crucial for the overall development of children 
Potić, S. et al. - Physical recreational activities and persons with disability

2014. Fakultet za sport i turizam, Novi Sad, TIMS Acta 8, 71-80

with visual impairment.

Due to the lack of vision, children with visual impairment have unique motoric needs. The effects of visual impairment on development are multiple: 1) children are delayed in reaching of developmental stages as a result of the lack of visual input, visual stimuli and various hints from the environment; 2 ) they are not able to observe and imitate movements of others, as can children from general population - this is the reason why bad body posture is often found in blind and partially sighted children; 3 ) they have fewer opportunities and impulses to participate in activities that provide the usual stimulation to children from the general population; 4) they need more time, additional assistance and more repetitions to master an activity (Lieberman et al., 2002).

The lack of mobility in children with visual impairment reduces the motivation to participate in physical activities, which, in return, reduces physical fitness. Muscle weakness, balance problems and low cardiovascular endurance are also a consequence of the lack of physical activities (Lockette \& Keyes, 1994).

In their paper, Perkins et al. (2013) emphasize that reduced participation of children with visual impairment in physical activities is partly a direct result of visual impairment and that other barriers include:

- lack of opportunities for recreation and playing sports - Perkins et al. (2013) report that children with visual impairment most often participate in physical activities at home, as well as that these activities are organised by adults, usually mothers, which represents the risk of developing social isolation;

- lack of appropriate adapted or specially designed equipment - there is an equipment that is necessary for teaching of physical education to children with visual impairment, among which Lieberman et al. (2002) allocate sound balls, bright colours balls, light balls (for beach) or balloons, various tactile limiters, colour lines, trainers, etc.;

- regular schools teachers are not familiar with modifications that can be carried out, which can be solved by additional training or consultation with experts, when there is a need for that;
- limited time for conducting of physical education teaching or for engaging in recreational activities and children with visual impairment need more individual work than their peers from general population.

Unless there is an encouragement for the engagement in physical and recreational activities in working with blind and partially sighted children, it is possible that problems (and/or delay) in gross and fine motor skills development, mobility problems and even difficulties in domain in daily living skills may occur (Tutt et al., 2012).

Overprotection of children due to lack of information represents a particular problem. Many parents do not want their children to be physically active, because they are afraid of potential injuries. Furthermore, low expectations that parents have from children can be obstacles for the involvement in physical and recreational activities. Lockette and Keyes (1994) believe that these problems can be overcome by additional education specifically designed for parents. It is important for them to be familiar with the benefits of physical activities in order to encourage children to engage in these activities.

Aslan et al. (2012) have realised research that was aimed to determine the level of physical activities in children and adolescents with visual impairment and to evaluate the effect that gender and level of visual impairment have on physical activities of blind and partially sighted children and adolescents. No statistically significant differences in the realization of physical activities were found in this research. As for the influence of gender, there were significant differences in favour of boys. What the authors have noticed was that blind and partially sighted children and adolescents tended to participate in light activities and activities of moderate difficulty, while a small number of respondents from the sample participated in vigorous activities. Decreased participation in physical activities leads to lower fitness of children with visual impairment in comparison to their peers of typical development, and to underdeveloped motor skills. Another problem is the fact that children with visual impairment often attend boarding schools, where the time for sleeping, walking, learning, eating, playing, etc. is predetermined. The study found differ- 
ences in favour of partially sighted boys and the authors (Aslan et al., 2012) assumed that visual perception present in partially sighted children was "culprit" for the found difference.

Movahedi et al. (2011) conducted a study in which they examined whether there was a difference in the social development of pupils with visual impairment who played sports and those who were not involved in sport or physical activities. Respondents who were involved in sports had better results than their peers who were not involved in any form of physical activities. The authors conclude that physical activities and sports games have a key role in psychosocial development, and that participation in physical activities enables the formation of social relations and friendly connections, and improves the group cohesiveness.

It is necessary to pay attention to the choice of activities while working with blind and partially sighted children. Teachers usually choose activities that are not dependent on visual input and feedback, and those that do not require major modifications. Lieberman and Houston-Wilson (2011) list some of activities that can be implemented in work with children with visual impairment, and that require minimal adaptation: folk dances, a tandem bike (with person who sees in the front seat), soccer, volleyball, basketball, corrective gymnastics, wrestling, etc.

If adaptations are necessary, it is important to focus on the child's residual senses, especially the sense of touch and the sense of hearing, but also the vision, if there are vision remnants. Child safety is something that should not be questioned under any circumstances, because, for example, a ball hit on the head could pose a great risk for children with visual impairment. Furthermore, teachers should take into account that difficulties in orientation and perception of space are present in children with visual impairment (fragmented perception, lack of perception of the third dimension, i.e. depth of space, etc.), so this should particularly be taken into consideration when organising group games. From the aforementioned, it is clear that a child with visual impairment will have difficulties in following the ball that is moving towards him. Therefore, the possible adaptation is to use smaller, lighter and softer balls (even beach balls can be considered). Improving of the visibility of equip- ment for children with visual impairment facilitates their space orientation - this is usually done by sticking tape of vibrant colour on the basket, net (or contrasting colour to the ground); strips of different colours can be put through the volleyball net; another option is to adjust the lighting levels by reducing glare and by improving contrast in the case of indoor activities.

The same authors (Lieberman and Houston-Wilson, 2011) suggest that when the implementation of specific activities requires vision, it may be helpful if a teacher divides activity into smaller steps and do each separate part with the child, so that the child could know what to expect - e.g. how many steps it should make in order to arrive from one end of the hall to another, and so on. If a teacher wants to include children with visual impairment in swimming, one of the adaptation strategies for children is to remember how many swings they need to make from one side of the pool to another and then to count as they swim; also, one of the options is to be touched by their coach when they get close to the edge of pool. If a child wants to engage in gymnastics, it is possible to use gym mats of different textures and colours in order to facilitate orientation. If a child expresses a desire to engage in dance, music and background of different colours and textures will help them to orient in space.

In addition to adaptation of activities in which the children from general population participate, there are also sports that are intended only for children with visual impairment. One of them is Goalball - played with a sound ball, and all participants wearing blindfold (regardless of the level of visual impairment). Benefits of this game are multiple, but perhaps the most important is that it encourages children to move around.

In addition to all of the above, physical activities are very useful also in a domain of social development because blind or partially sighted children, while participating in, feel like a part of the group, they learn to cooperate with members of the same team, they do not depend on the help of others, but do understand that they themselves can make a decision or do something for their own team.

Children and young persons with visual impairment participate in physical-recreational activities less often than their peers of typical development. Without the 
Potić, S. et al. - Physical recreational activities and persons with disability

2014. Fakultet za sport i turizam, Novi Sad, TIMS Acta 8, 71-80

possibility to participate in leisure and physical activities, they are not able to explore their social, intellectual, emotional, physical and communicative potential, and they are less able to grow and develop as individuals. Therefore, physical activities are clearly important to children with visual impairment.

\section{Physical-recreational activities and persons with autism}

Autistic spectrum disorder is characterised by deficits in domains of social interaction, communication, and by restricted, repetitive and stereotyped patterns of behaviour and interests (APA, 2000). Persons with autism have difficulties in achieving and maintaining of social contacts, reciprocal social-emotional relations, they exhibit problems in verbal and nonverbal communication, imagination, as well as unusual behaviour accompanied by compulsive adherence to non-functional motor mannerisms, routines and rituals (APA, 2000).

These mentioned specifics of autistic disorder can affect the possibility for persons with this disorder to engage in recreational activities. Results of conducted studies show that young persons with autism are involved in physical and recreational activities on a daily and weekly basis to an extent lesser than expected (Pan \& Frey, 2006). In monitoring and measuring of the level of physical activities by applying Accelerometry in 30 participants with autistic disorder, aged 10-19 years, Pan and Frey pointed out that daily continuous physical activity for 60 minutes was not recorded in any of participants, that there were no differences in the physical engagement of participants during the weekend and week days, and that the time for physical activities usually ranged from 5 to 20 minutes during the day. Taking into account the fact that all participants were included by the education system and that their physical and recreational activities were monitored during their staying at school, one can conclude that it is necessary to add programs of physical activities to the content of educational program. Physical activity that is minimally present may adversely affect the health status of persons with autism.

Using the technique of Accelerometry in their research, Bandini et al. (2012) went a step further and compared the level of physical activities in children with autism and their peers of average abilities. The sample included 53 participants with autistic disorder and 58 children from general population, all participants had between 3 and 11 years of age. Results showed that the children who did not have autism participated in more varied physical activities during the daytime and spend more time in these activities in comparison with children who had autism. Out of the total sample of children with autistic disorder, only $23 \%$ of participants performed physical activities for 60 minutes each day. One of the potential limitations of studies that use accelerometers in assessing of physical activities level in persons with autism is the fact that the aforementioned technique also records those senseless, dysfunctional, stereotyped and repetitive movements that persons with autism may manifest, and registers them as physical activities.

Having in mind that children with autistic disorder rarely engage in physical activities spontaneously and voluntarily, the need for designing of directed programs that will provide support for these persons for equal participation in recreational and sports activities is therefore registered. Schlein et al. (1987) actually emphasize that children with autism can be integrated into the peer group successfully by the implementation of structured program of sports and recreational activities that their behaviour can be modified by minimization of inappropriate behaviour patterns and more frequent occurrence of preferable behaviour. In their research, aforementioned authors followed two children with autism during three-week training within the peer group. Physical activities divided into three sessions were performed daily - cooperative sports games, swimming and gymnastics. Participants were evaluated before, during and after completion of the training program. The obtained results indicate that such programs of sports activities contribute not only to physical fitness of participants, but that they are also reflected in the improvement of clinical picture, as well as in the level of acceptance of children with autism by their peers. In a study of similar design, the authors (Schlein et al., 1988) follow six children with autism during the nine-week program of physical education within a group of fifty peers of average abilities. The obtained results show that the structured training contributes to an increased inclusion of children with autism in sport activities, to an improvement of motor skills, as well as to the reduction of inappropriate ways 
of behaviour.

Besides specialised services, such as those organised programs of recreational and sport activities, additional factors that determine the integration of children with autism in leisure activities in a community are higher degree of engagement of mothers in the same activities, and the education of children in inclusive terms (Glumbić, 2006).

Analysing the most common recreational activities in persons with autism, Orsmond et al. (2004, according to Glumbić, 2006) indicate that the most frequent are walking and exercising, seeing as three-quarters of participants perform them daily and explain that by the characteristics of these activities. Namely, these activities do not require excessive social contact with surroundings and therefore suit the nature and specific features of the clinical picture of autism. On the other hand, the same authors point out that one-third of participants takes part in group physical-recreational activities. Those are respondents whose parents or other family members are involved in such activities.

The findings about the positive effects of sport and physical-recreational activities on physical health, behavior, but also on social integration of persons with autism should be used in creating of educational and therapeutic programs of working with these persons.

\section{Physical-recreational activities and with intellectual disability}

Intellectual disability (hereinafter: ID) is characterised by significant limitations both in intellectual functioning and adaptive behaviour, whereby it occurs before the age of eighteen (AAMR, 2002). Deficits in adaptive behaviour can be observed in social, conceptual and/or practical area of adaptive skills.

Generally, these mentioned limitations may reduce the possibility for children and adults with ID to engage in various recreational activities on an equal basis as the members of general population. Some authors note that persons with mild ID have poorer performances on manual tasks that require integration of visual inputs and arm movements than persons of typical development (Carmeli et al., 2008), whereby poorer visuomotor coordination may have a functional impact, i.e. may lead to the exclusion of persons with mild ID from working and leisure activities. Considering the potential risk factors that can be associated with reduced involvement in physicalrecreational activities, some authors suggest that the presence of challenging behaviour in persons with ID can represent a limiting factor (Ashwortha et al., 2009).

The previously mentioned is supported by the research in which the average numbers of social, recreational and leisure activities in three groups of participants were compared - children of typical development, children from the autism spectrum disorders and children with ID (Solish et al., 2010). The authors defined recreational activities as the structured ones and opposed to social activities (as more formally organised ones), such as team sports and lessons (e.g. music lessons, dance, swimming, playing soccer, hockey, etc.). Results indicated that children with ID and autism were involved in significantly fewer recreational activities in comparison to their peers of typical development, and that no statistically significant differences in terms of practicing of these activities were observed between these two groups of children with disabilities. Furthermore, it was noted that children of typical development participated in recreational activities together with their peers more often than in the case of children with ID or children with autism. The last two groups of participants had significantly less formed reciprocal friendships with peers when compared to children of typical development. Therefore, in the light of a more pronounced need for implementation of social inclusion for persons with disabilities, the authors of this study emphasize the importance to examine not only the involvement of children with disabilities in certain activities, but also to examine with whom they are realising these activities.

Abells et al. (2008) gave descriptive data concerning the participation of 63 adolescents with ID in social, recreational, and religious activities. According to the statements of parents or caregivers, who were informants in this study, fifty children were involved in activities together with their family members or personnel, and forty were involved in activities with their peers. Physical activities, such as walking or swimming, were the most common activities performed with family members or personnel, while organised sports activities were the most frequent type of activities that adolescents with 
Potić, S. et al. - Physical recreational activities and persons with disability

2014. Fakultet za sport i turizam, Novi Sad, TIMS Acta 8, 71-80

ID realised with peers. On the other hand, participation in unorganised activities with peers was quite rare, so Abells et al. (2008) believe that the interaction between adolescents with ID and their peers does not always occur naturally. Therefore, organised opportunities for social interaction, such as organised sports activities, may be needed in order to facilitate social inclusion of children with ID.

Some authors suggest that persons with ID, as well as those of typical development, can have multiple benefits from physical-recreational activities in which the interaction between these two groups of people is enabled. These interactions provide an opportunity for persons with ID to engage in important and age-appropriate activities. Furthermore, these interactions encourage social relationships with peers of typical development, improve physical and mental health of person with ID, facilitate their skills development and improve their perception of belonging to the community (Brower et al., 1997, according to Mahon et al., 2000). On the other hand, persons of typical development are provided with an opportunity to get to know persons with ID more closely, with consequently less focus on individual differences, but with greater sharing of common interest in physical-recreational activities (Green et al., 1995, according to Mahon et al., 2000).

However, there are papers in literature (Duvdevany, 2002; Ninot et al., 2005) that emphasize that persons with ID who participate in physical-recreational and sports activities in a community, can compare themselves with more competent peers of typical development, which may lead to consequentially poorer perception of their own physical performances. Although physical-recreational activities that are carried out in a community provide opportunities for social integration of persons with ID, these activities, on the other hand, can sometimes encourage persons with ID to perceive differences in relation to persons of typical development.

\section{Physical-recreational activities and persons with cere- bral palsy}

Participation in physical recreational activities of persons with physical disabilities results in a better health status, increased functional independence, as well as in many psychological benefits such as more adequate self-image, higher self-esteem and higher levels of selfsatisfaction (Shephard, 1991, according to Crawford et al., 2008). Majnemer et al. (2008) state that active engagement in meaningful physical activities is necessary for promotion of health and personal autonomy, development of skills and functional productivity, social integration and life satisfaction. Hanson et al. (2001) report that persons with physical disabilities who are active in sports show a high level of achieved social participation and this is supported by the results of research conducted by Crawford et al. (2008) showing that persons with physical disabilities that practiced physical activities more achieved a higher level of integration and a greater extent of social participation in other activities within the community, in comparison to persons with physical disabilities who were less physically active. It is documented that physical activities or at least some of them, such as swimming, are significant means of rehabilitation for population of persons with physical disabilities (Özer et al., 2007; Hutzler et al., 1998).

Compared to the typical population, due to their motor difficulties, persons with cerebral palsy have less opportunity to participate in many activities in their environment, including physical activities (Nedović et al., 2012; Imms, 2008; Maher et al., 2007). Literature data suggest that factors of importance for participation in physical activities in the population of persons with cerebral palsy are their level of motor abilities and age (Claassen et al., 2011; van Eck et al., 2008). It turned out that a reduction of participation in physical activities of persons with cerebral palsy occurs with the age increasing (Brunton \& Bartllet, 2010; Orlin et al., 2010), which could be related to the decline of functional abilities and the occurrence of secondary problems typical for this population, such as the loss of ability to walk, development of skeletal deformities, pain amplification and intensification of fatigue when performing daily activities (Milićević \& Potić, 2012). In addition to this, a lower level of participation in physical activities is recorded in those persons with cerebral palsy who have severe motor impairments in comparison to those who are functioning at a higher motor level (Brunton \& Bartllet, 2010; Orlin et al., 2010).

Problems related to participation of persons with cerebral palsy in recreational and physical activities are 
various. Primary motor impairment itself causes inactivity and reduced mobility in children with cerebral palsy, due to which they are rendered drastically passive in comparison to their peers from typical population. This is supported by the research findings of Blum et al. (1991). These authors suggest that predominant activities of school aged children with cerebral palsy in leisure time are passive entertainment (watching TV) and active leisure activities (playing chess), while the least frequent activities in organised leisure are mobile activities, such as recreation or sports. Furthermore, reduced participation in physical activities occurs due to overprotection of children with cerebral palsy by their parents, manifested in excessive support provided in performing any activity and recommendation to avoid certain potentially risky daily activities, which all leads to avoiding numerous physical activities. The problem can be seen in the fact that children with cerebral palsy quite often, regardless of the inclusiveness of surroundings, and even at an early age, tend to play alone and fix a pattern of individual playing as the dominant one, due to inability to equally participate in joint activities with their peers (Tamm \& Skar, 2000), whereby this tendency towards social selfexclusion may persist even during adolescence (Sandberg et al., 2004). Negative experience gained during the realization of group activities (Sandberg et al., 2004) and the problem of social contacts achievement (Blum et al., 1991), as well as victimization, may be barriers to inclusion of this population in organised, group recreational activities. On the other hand, the inclusion of children with cerebral palsy in individual recreational activities can become problematic due to the lack of experience and lack of motivation, but also for psychological reasons. In addition, the reasons for reduced participation of this population in recreational and physical activities in general can be found in barriers that originate from the environment itself.

Due to the nature of impairment, persons with physical disabilities are often engaged in adapted physical activities, adjusted to abilities of this population. Research shows that participation in adapted physical activities has a positive effect on overall health and quality of life, with emphasis on the quality of family and social life in population of persons with cerebral palsy (Groff et al., 2009).

\section{Instead of conclusion}

Participation of persons with disabilities in physical recreational activities within the community is determined by individual characteristics of each person, but also by social/community factors. The results of numerous studies show that persons with disabilities participate less in leisure and recreational activities and that it is largely related to the low level of social integration of these persons.

Considering that the participation of persons with disabilities in physical recreational activities largely correlates to the quality of life of these persons, it is necessary to increase the number of recreational services that community offers to persons with disabilities and to specialise some of them or modify and adapt them according to needs of these people. In addition to this, it is recommended to train the persons with disabilities to use their leisure time appropriately as an integral part of all therapeutic approaches to these people.

\section{REFERENCE}

Abells, D., Burbidge, J., \& Minnes, P. (2008). Involvement of Adolescents with intellectual disabilities in social and recreational activities. Journal on Developmental Disabilities, 14(2), 88-94.

-American Association on Mental Retardation. (2002). Mental Retardation: Definition, Classification, and Systems of Supports, 10th ed. Washington: American Association on Mental Retardation.

-American Psychiatric Association. (2000). Diagnostic and statistical manual of mental disorders, 4th ed. Washington: American Psychiatric Association.

Ashworth, M., Hirdes, J.P., \& Martin, L. (2009). The social and recreational characteristics of adults with intellectual disability and pica living in institutions. Research in developmental disabilities, 30(3), 512-20. pmid:18789647

Aslan, U.B., Calik, B.B., \& Kitiş, A. (2012). The effects of gender and level of children and adolescents with visual impairment. Research in developmental disabilities, 33(2), 1799-804. pmid:22699253

Bandini, L.G., Gleason, J., Curtin, C., Lividini, K., Anderson, S.E., Cermak, S.A., \& Must, A. (2012). Comparison of physical activity between children with autism spectrum disorders and typically developing children. Autism, 17(1), 44-54. pmid:22807562

Blum, R.W., Resnick, M.D., Nelson, R., \& st Germaine, A. (1991). Family and peer issues among adolescents with spina bifida and cerebral palsy. Pediatrics, 88(2), 280-5. pmid:1861926

Brunton, L.K., \& Bartlett, D.J. (2010). Description of exercise participation of adolescents with cerebral palsy across a 4-year period. $P e$ diatric Physical Therapy, 22(2), 180-7. pmid:20473101

Carmeli, E., Bar-Yossef, T., Ariav, C., Ran Levy, R., \& Liebermann, D.G. (2008). Perceptual-motor coordination in persons with mild intellectual disability. Disability and Rehabilitation, 30(5), 323-9. pmid:17852209 
Claassen, A.A.O.M., Gorter, J.W., Stewart, D., Verschuren, O., Galuppi, B.E., \& Shimmell, L.J. (2011). Becoming and staying physically active in adolescents with cerebral palsy: protocol of a qualitative study of facilitators and barriers to physical activity. BMC pediatrics, 11(1), 1. pmid:21214908

Crawford, A., Hollingsworth, H.H., Morgan, K., \& Gray, D.B. (2008). People with mobility impairments: Physical activity and quality of participation. Disability and Health Journal, 1(1), 7-13. pmid:21122706

Duvdevany, I. (2002). Self-concept and adaptive behaviour of people with intellectual disability in integrated and segregated recreation activities. Journal of Intellectual Disability Research, 46(Pt 5), 41929. pmid:12031024

Glumbić, N. (2006). Odrasle osobe sa autizmom. Kragujevac: Izdavačka agencija ,"Grad".

Groff, D.G., Lundberg, N.R., \& Zabriskie, R.B. (2009). Influence of adapted sport on quality of life: Perceptions of athletes with cerebral palsy. Disability \& Rehabilitation, 31(4), 318-326.

Hutzler, Y., Chacham, A., Bergman, U., \& Szeinberg, A. (1998). Effects of a movement and swimming program on vital capacity and water orientation skills of children with cerebral palsy. Developmental Medicine \& Child Neurology, 40(3), 176-181.

Imms, C. (2008). Children with cerebral palsy participate: a review of the literature. Disability \& Rehabilitation, 30(24), 1867-1884.

Lieberman, L.J., Houston-Wilson, C., \& Kozub, F.M. (2002). Perceived barriers to including students with visual impairments in general physical education. Adapted Physical Activity Quarterly, 19(1), 364-377.

Maher, C.A., Williams, M.T., Olds, T., \& Lane, A.E. (2007). Physical and sedentary activity in adolescents with cerebral palsy. Developmental Medicine \& Child Neurology, 49(6), 450-457.

Mahon, M.J., Mactavish, J., Bockstael, E., O’Dell, I., \& Siegenthaler, K.L. (2000). Social integration, leisure and individuals with intellectual disability. Parks \& Recreation, 35(4), 25-34.

Majnemer, A., Shevell, M., Law, M., Birnbaum, R., Chilingaryan, G., Rosenbaum, P., \& Poulin, C. (2008). Participation and enjoyment of leisure activities in school-aged children with cerebral palsy. Developmental Medicine \& Child Neurology, 50(10), 751-758.

Milićević, M., \& Potić, S. (2012). Funkcionalne sposobnosti odraslih osoba sa cerebralnom paralizom. Beogradska defektološka škola, 18(1), 141-156

Movahedi, A., Mojtahedi, H., \& Farazyani, F. (2011). Differences in socialization between visually impaired student-athletes and nonathletes. Research in Developmental Disabilities, 32(1), 58-62. pmid:20880667

Nedović, G., Rapaić, D., Odović, G., Potić, S., \& Milićević, M. (2012). Socijalna participacija osoba sa invaliditetom. Beograd: Društvo defektologa Srbije.

Ninot, G., Bilard, J., \& Delignières, D. (2005). Effects of integrated or segregated sport participation on the physical self for adolescents with intellectual disabilities. Journal of intellectual disability research ,49(Pt 9), 682-9. pmid:16108985. doi:10.1111/j.13652788.2005.00407.x

Orlin, M.N., Palisano, R.J., Chiarello, L.A., Kang, L.J., Polansky, M., Almasri, N., \& Maggs, J. (2010). Participation in home, extracurricular, and community activities among children and young people with cerebral palsy. Developmental Medicine \& Child Neurology, 52(2), 160-166.

Özer, D., Nalbant, S., Aktop, A., Duman, O., Keleş, I., \& Toraman, N. (2007). Swimming training program for children with cerebral palsy: body perceptions, problem behaviour, and competence 1 .
Perceptual and Motor Skills, 105(3), 777-87. pmid:18229533

Pan, C., \& Frey, G.C. (2006). Physical activity patterns in youth with autism spectrum disorders. Journal of Autism and Developmental Disorders, 36(5), 597-606. pmid:16652237. doi:10.1007/s10803006-0101-6

Sandberg, A., Björck-Åkesson, E., \& Granlund, M. (2004). Play in retrospection: Play experiences from childhood in adults with visual disability, motor disability and Asperger syndrome. Scandinavian Journal of Disability Research, 6(2), 111-130.

Schleien, S., Heyne, L., \& Berken, S. (1988). Integrating physical education to teach appropriate play skills to learners with autism: A pilot study. Adapted Physical Activity Quarterly, 5(1), 182-192.

Schleien, S., Krotee, M., Mustonen, T., Kelterborn, B., \& Schermer, A (1987). The effect of integrating children with autism into a physical activity and recreation setting. Therapeutic Recreation Journal, 21(4), 52-62.

Solish, A., Perry, A., \& Minnes, P. (2010). Participation of children with and without disabilities in social, recreational and leisure activities. Journal of Applied Research in Intellectual Disabilities, 23(3), 226-236.

Tamm, M., \& Skär, L. (2000). How i play: Roles and relations in the play situations of children with restricted mobility. Scandinavian Journal of Occupational Therapy, 7(4), 174-182.

Tutt, L.M., Lieberman, L., \& Brasher, B. (2012). Physical education for students with visual impairments. Position paper of the division on visual impairments. Arlington, VA: Council for Exceptional Children.

van Eck, M., Dallmeijer, A.J., Beckerman, H., van den Hoven, P.A.M., Voorman, J.M., \& Becher, J.G. (2008). Physical activity level and related factors in adolescents with cerebral palsy. Pediatric exercise science, 20(1), 95-106. pmid:18364538

Lockette, K. F., \& Keyes, A. M. (1994). Conditioning with physical disabilities. Champaign, IL: Human Kinetics.

Lieberman, L. J., \& Houston-Wilson, C. (2011). Strategies for Increasing the Status and Value of Adapted Physical Education in Schools. Journal of Physical Education, Recreation \& Dance, 82(6), 25-28.

Perkins, K., Columna, L., Lieberman, L., \& Bailey, J. (2013). Parents' perceptions of physical activity for their children with visual impairments. Journal of Visual Impairment \& Blindness, 107(2), 131-142.

Hanson, C. S., Nabavi, D., \& Yuen, H. K. (2001). The effect of sports on level of community integration as reported by persons with spinal cord injury. The American Journal of Occupational Therapy, 55(3), 332-338.

Caspersen, C. J., Powell, K. E., \& Christenson, G. M. (1985). Physical activity, exercise, and physical fitness: definitions and distinctions for health-related research. Public health reports, 100 (2), 126131.

Datum prijave rada: 28.01.2014.

Datum prihvatanja rada: 21.03.2014.

\section{Kontakt}

Srećko Potić, High Medical School of Professional Studies "Milutin Milanković", Belgrade, Crnotravska 27

E-mail: sreckopotic@gmail.com 
Potić, S. et al. - Physical recreational activities and persons with disability

2014. Fakultet za sport i turizam, Novi Sad, TIMS Acta 8, 71-80

Ksenija Stanimirov, University of Belgrade - Faculty of Special Education and Rehabilitation, Belgrade, Visokog Stevana 2

E-mail: ksenija.stanimirov@gmail.com

Mirjana Đorđević, University of Belgrade - Faculty of Special Education and Rehabilitation, Belgrade, Visokog Stevana 2

E-mail: mira.djordjevic81@gmail.com

Slobodan Banković, University of Belgrade - Faculty of Special Education and Rehabilitation, Belgrade, Visokog Stevana 2

E-mail: slobodan2008@yahoo.com 